\title{
17: 40192094-40213504
}

National Cancer Institute

\section{Source}

National Cancer Institute. 17: 40192094-40213504. NCI Thesaurus. Code C41649.

Physical location of ADAM11_Gene 